\title{
Přístupy k historické architektuře v českých muzeích v prírodě
}

\section{Approaches to the Historical Architecture in the Czech Open Air Museums}

Abstract: Open-air museums have been a part of the European museology for about one and a half century and it has been an architectural object that has been the main and defining element of this type of museum since the beginning. However, the importance of the buildings varies not only with the specific state of the society and of the relevant field, but also with the current state of museum institutions. Accordingly, the approach to the very matter of buildings and their craftsmanship is also varying. Possible reconstructive construction works are influenced not so much by finances as by the insufficient methodological base, the lack of qualified museum specialists, and especially by the lack of quality craftsmen. The importance of buildings is also determined by the primary mission of the open-air museums, which are ideally a comprehensive reconstruction of the historic environment, where the building can become, despite its importance, only one of the elements. It is on the construction objects where a number of values are preserved, represented by specific details both on the material and intangible (technological) level. Very important is also the role of an open-air museum as a model, an authority for many private owners of the heritage monuments.

Keywords: open-air museums, historic preservation, museology, vernacular architecture, architecture, craft, authenticity, originality

\section{Muzeum v přírodě jako interdisciplinární fenomén}

Muzea v př́rodě v Evropě jsou kulturním fenoménem již takřka jedno a půl století a právě architektonický objekt byl od počátku hlavním a určujícím prvkem tohoto typu muzeí. Přestože nebo právě proto, že jsou stavby nejdůležitější esencí muzeí v př́rodě, je smysl objektů proměnný nejen s konkrétní situací ve společnosti a v př́slušném oboru, ale proměnný také s aktuálním stavem těchto institucí i konkrétními vůdčími osobnostmi v muzeích. Podle toho se proměňuje také přístup $\mathrm{k}$ samotné materii staveb a jejich řemeslnému provedení. ${ }^{1}$

Nejednoduché je i právě vymezení samotného oboru, který se tímto typem muzeí zabývá. Přestože již takřka půl století je $\mathrm{v}$ diskusi představitelů muzeí $\mathrm{v}$ př́rodě v naší zemi snaha o vytvoření jednotné metodiky, je i tento nevelký segment pamětových institucí ve své metodologii značně diferencovaný. Tato rozdílnost je pro muzea $\mathrm{v}$ prírodě př́íznačná nejen u nás, ale roste s poznáním zahraničních muzeí. ${ }^{2}$ Každé muzeum v prrírodě je tedy závislé na interdisciplinární souhře různých odborných zaměření, která by měla být $\mathrm{v}$ precizní rovnováze, ale zpravidla některé vyniká.

Primární specializací, která se do činnosti muzeí v př́rodě včetně své legislativy promítá, je památková péče se snahou záchrany staveb prímo na původních místech, jež se následně mohou stát součástí muzea. Také při každodenním provozu, a to i v př́padě staveb transferovaných na nové místo, bývá pohled památkáře velmi důležitý a zcela zásadní. Zde už není daleko k oboru urbanismu a architektury,
1 Článek vznikl na základě institucionální podpory dlouhodobého koncepčního rozvoje výzkumné organizace poskytované Ministerstvem kultury. 2 LANGER, Jiří. Evropská muzea v prírodě. Praha: Baset, 2005 , s. $13-16$.

Mgr. Radek Bryol Národní muzeum v prírodě radek.bryol@nmvp.cz. 


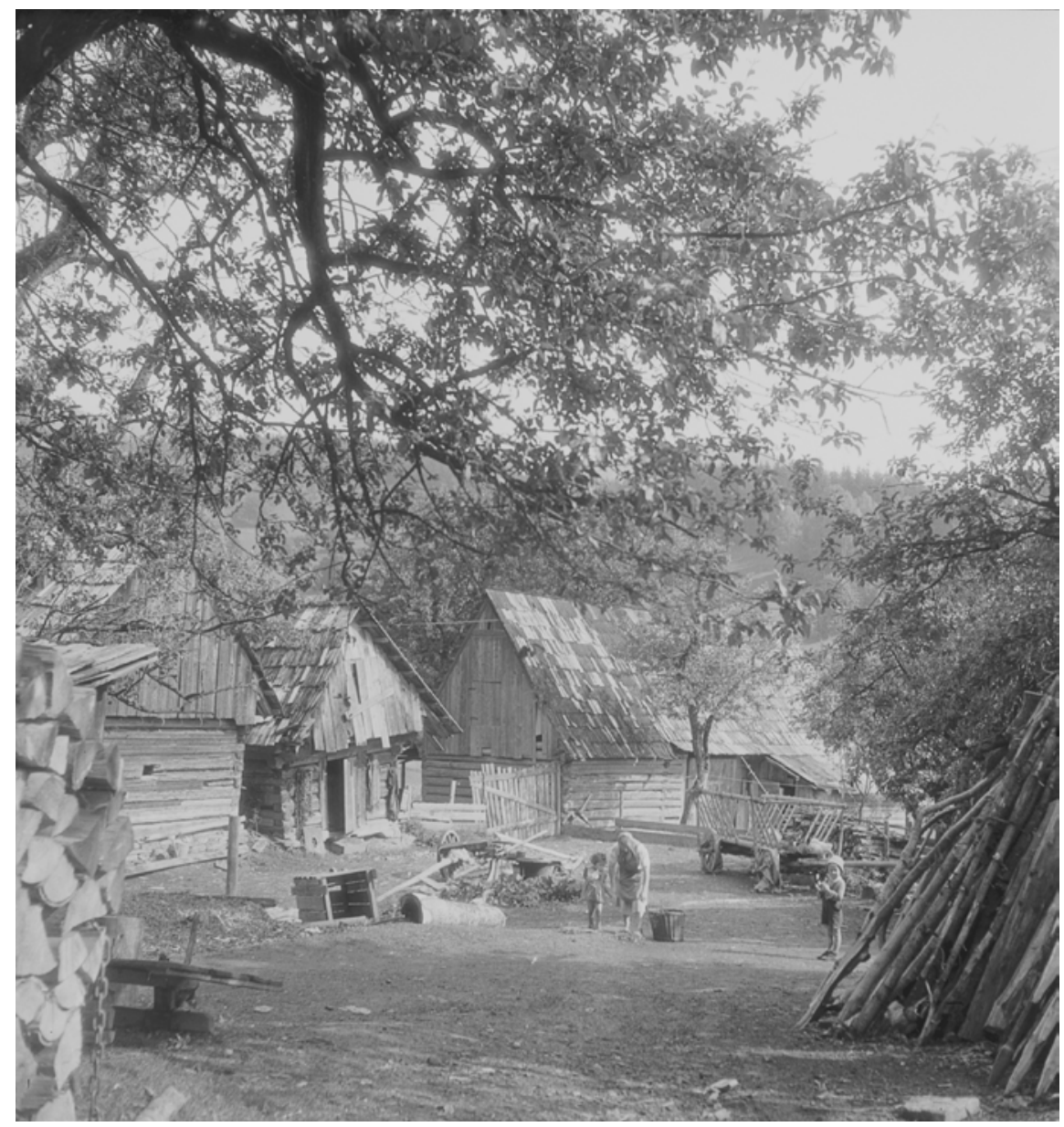

Autenticitě staveb napomáhají zdánlivé detaily jako napríklad lokální opravy šindelů. Tak jako se běžně dělo, když ještě stály $v$ terénu, pol. 20. století (Oddělení dokumentace VMP, NMvP)

3 Právě stavebnětechnické obory s charakterem spiše komerčním, jejichž predstavitelé uvažují v intencích současné moderní výstavby a památky jsou jim bud' na obtíž, nebo $v$ nikoli lepším prípadě $k$ obhájení jejich komerčních zájmů a kumulaci referencí, mohou být $v$ současné době pro muzea nejzhoubnějši hrozbou.

4 VÁLKA, Miroslav. Lidový dům a jeho role při formování národní identity. Prameny a studie, 2015,56 , s. 147-158.

5 LANGER, Jiří a ŠTIKA, Jaroslav. Ceskoslovenská muzea v prírodě. Martin: Osveta, 1989 , s. $20-21$.

6 TYKAL, Roman. Český mlýn na Národopisné výstavě českoslovanské. Prameny a studie, 2015, 56, s. 191-195.

7 SMRČKA, Vit. Dějiny psané národopisem. Praha: Ceská národopisná společnost, 2011, s. 39-53; Za konzultaci děkuji také PhDr. Jiřímu Langrovi, CSC. který pracuje se základními prvky muzea. Muzeologie rovněž prostřednictvím zákona o sbírkách reprezentuje v muzeu $\mathrm{v}$ přírodě řád práce se sbírkami. $\mathrm{V}$ našem prostředí je muzeum $\mathrm{v}$ přírodě reprezentantem zvláště venkovské kultury. Proto je rozhodujícím oborem etnologie, případně historie, jako disciplíny, které mohou určovat celkové koncepční pojetí expozice. Tímto výčet odvětví zdaleka nekončí. Za důležitou považujeme dále archeologii, konzervátorství a restaurátorství, dendrochronologii, a zvláště stavebnětechnické obory, které obvykle nemají vliv na samotnou koncepci, ale jsou důležité $\mathrm{k}$ vědění o uchovávaných památkách. Do jednotlivých mnohdy důležitých detailů pak zasahují právě externí odborníci různých kvalit, kumulující se kolem dotyč-

Po historickém úvodu se zaměříme zejména na současné problémy stavebních aktivit, a to podrobněji na Valašské muzeum v přírodě v Rožnově pod Radhoštěm. Pokusíme se odpovědět, jaký byl v průběhu existence muzeí v přírodě smysl stavebních památek v nich a jak se proměňovala péče a řemeslné dovednosti, stejně jako celková atmosféra práce muzeí ného muzea. ${ }^{3}$ v přírodě. Snažíme se definovat, jaké jsou konkrétní závislosti určité epochy na kvalitě řemeslného provedení staveb v muzeích v přírodě.

Pro tento text čerpáme z poznání současného stavu památkových objektů $\mathrm{v}$ muzeích $\mathrm{v}$ přírodě, $\mathrm{z}$ analýzy publikovaných textů o výstavbě muzeí $\mathrm{v}$ přírodě, stejně jako z koncepčních materiálů těchto muzeí.

\section{Počátky v našich zemích}

Prvním rozsáhlejším pokusem protomuzejnictví v přirodě $\mathrm{v}$ našich zemích byla již tolikrát zmiňovaná výstavní dědina na Národopisné výstavě českoslovanské v Praze roku 1895. Hlavním posláním zde byla reprezentace české kultury, zejména představení rozmanitosti jednotlivých regionů českých zemí a částečně Slovenska v rámci habsburské monarchie. Provedení staveb bylo různé v závislosti na osobnostech, které se v určitých regionech účastnily příprav. Dưležitou roli v celém procesu výběru hrála snaha o ukázku těch nejreprezentativnějších prvků pro regionální architekturu. ${ }^{4}$ Ve výstavní vesnici se poté objevila vedle sebe celá typologická plejáda prrístupů $\mathrm{k}$ rekonstrukcím staveb: od originálu $\mathrm{v}$ př́ípadě pily $\mathrm{z}$ Valašska ${ }^{5}$ či původní doškové střechy dokonce porostlé mechem a netřeskem získané pro český mlýn ${ }^{6}$ až po různě věrné kompiláty jednotlivých usedlostí. Hlavní účel byl nad očekávání splněn. Tím zde nebyla záchrana staveb, ale představení jejich různosti a umělecké hodnoty, rozmanitý řád způsobu života $\mathrm{v}$ různých kulturně sociálních prostředích a v neposlední řadě také vytvoření zázemí pro výstavní aktivity i dokonalou kulisu celému dění.?

Také v dalších muzejních počinech, již na počátku 20. století, cítíme důležité vnímání využití staveb pro vnitřní expoziční účely, tak jako u staročeské chalupy v Přerově nad Labem. ${ }^{8}$ Počátky Valašského muzea v př́irodě v Rožnově pod Radhoštěm již byly motivovány zejména záchranou staveb, ale nepopiratelná je také role zdůraznění specifičnosti konkrétní oblasti, tedy již 
patrné zúžení z nadšení slovanstvím při Národopisné výstavě na zájem o jeden národopisný region.

Přestože již $\mathrm{v}$ této době bylo $\mathrm{v}$ některých oblastech řemeslo vytlačováno průmyslovou výrobou a novými materiály ve stavebnictví, u těchto pionýrských počinů byla výhodou pro dosažení autenticity staveb př́tomnost řemeslníků, pro které byla ruční práce nevyhnutelnou samozřejmostí. Jeden z hlavních tvůrců rožnovského muzea Bohumír Jaroněk velmi chválil práci tesařského mistra Michala Fabiána při většině prvotních staveb: „Dosavadní budovy Musea v př́rodě jsou sice rekonstrukce originálů staveb, převezených z různých míst valašského kraje, leč tato práce rekonstruktívní vyžadovala rozvahy, paměti a důmyslu $i$ znalost tradic řemesla. Čeká ho však i práce novostavby: valašského Zemědělského musea ve stylu patrového dřevěného fojtství, které bude budováno na počátku přšstího roku. ${ }^{.9}$ Naprosto autentické zpracování staveb nebylo navíc $\mathrm{v}$ této době stále ještě prioritou, ale $\mathrm{v}$ duchu tendencí Národopisné výstavy je patrná snaha o využití reprezentativních prvků, jak se dovídáme např́ílad z opravy rožnovské radnice po první světové válce, ale také na dalších stavbách ještě po polovině 20. století. ${ }^{10}$ Úspěch a zájem kolem otevření Valašského muzea v př́rodě potvrdily správnost př́stupu s důrazem rovněž na oživení muzejního areálu. ${ }^{11}$ Přestože vznik tohoto muzea byl až do počátku 2. poloviny minulého století osamocenou aktivitou, která se podařila realizovat, cítíme i u neuskutečněných koncepcí velký důraz na propojení staveb se snahou o jejich oživení a v některých př́ipadech stavby měly tvořit prímo kulisu v pozadí amfiteátru. ${ }^{12}$

Komplexní prezentace lidové kultury, kde stavby byly důležitým, ale jen jedním z mnoha prvků byla později patrná také $\mathrm{v}$ realizované ideji muzea $\mathrm{v}$ př́rodě ve Strážnici, kde „nosnou myšlenkou návrhu bylo ukázat desetitisícuim návšstěrniku festivalu a dalších celostátních akcí lidovou kulturu $\checkmark$ její jednotě, od projevio folklórnich, lidového výtvarného umění a jevi̊ duchovní kultury lidu, až ke způsobu bydlení, hospodaření a lidové výrobě. Podmínky pro vytvoření tohoto celkového obrazu tradiční slovácké vesnice jsou ve Strážnici naplněny takřka ideálním způsobem. ${ }^{\text {13 }}$

\section{Hledání metody}

Nejvýznamnější epocha záchrany památek lidového stavitelství spadá do 60.-80. let 20. století, kdy byly objekty po politických a společenských změnách ohroženy nejen modernizacemi, ale nejprve také nezájmem př́slušných orgánů. Také snahy památkové péče o záchranu staveb $\mathrm{v}$ původním prostředí často narážely na rychlou proměnu jejich okolí a na potřeby majitelů modernizovat. Venkovské objekty zároveň mohly reprezentovat ideologií žádoucí projevy nejnižších sociálních vrstev.

V uvedeném období tak proběhla nejen rozsáhlá dostavba muzea $\mathrm{v}$ přírodě v Rožnově, ale povstala další muzea tohoto typu v naší zemi. Motivace regionální identitou byla $\mathrm{v}$ tomto čase již převrstvena potřebou záchrany mizejících, především dřevěných vesnických staveb zvláště $\mathrm{v}$ oblastech $\mathrm{s}$ jejich větší koncentrací, at' už v gesci profesionalizované památkové péče, muzeí, nebo nadšených dobrovolníků. ${ }^{14}$

Velmi důležitá byla $\mathrm{v}$ tomto období také vzájemná inspirace prací jednotlivých vznikajících muzeí $\mathrm{v}$ př́rodě na území Československa, přičemž právě na Slovensku vznikala muzea dříve, protože tam byly památkářské koncepce zcela odlišné od české záchranářské tradice. Další zdroje pro práci pocházely zejména z Polska a Rumunska. ${ }^{15}$

Nosným problémem, který se projevil např́klad na celostátní Konferenci o ochraně památek lidové architektury $\mathrm{v}$ roce 1958, byl zpočátku nesoulad názorů zástupců památkové péče, prosazujících zachování staveb in situ a odborníků z řad etnografů a muzejníků preferujících záchranu v muzeích $\mathrm{v}$ př́rodě. Po zjištění negativního vývoje stavu památek lidové architektury zapsaných na seznam právě v roce 1958 však začínala být také muzea $\mathrm{v}$ př́rodě tolerována jako možný prostor
8 LANGER, Jiří a ŠTIKA, Jaroslav. Československá muzea v prírodě. Martin: Osveta, 1989 , s. 27.

9 Národní muzeum v přirodě Valašské muzeum $v$ prírodě $v$ Rožnově pod Radhoštěm, Oddělení dokumentace, S III 01, Spolková činnost, Musejní spolek v Rožnově, inv. č. A 20082. 1929.10 BRYOL, Radek. Devadesát let transferů do Valašského muzea $v$ př́rodě $v$ Rožnově pod Radhoštěm. In: Transfer a rekonstrukce památek lidové architektury. Rožnov pod Radhoštěm - Sebranice: Valašské muzeum v prírodě Spolek archaických nadšenců, 2016, s. 12-29.

11 Např. ZíBRT, Čeněk. Valašské museum v prírodè. Český lid, 1928, 28, s. 154-159. 12 Např. PELUNĔK, Lukáš $F$. Neuskutečněné plány založení Bartošova národopisného musea $v$ prírodě. $K$ životnímu odkazu Ladislava Rutteho (1893-1967). In: WOITSCH, Jiři a JŮNOVÁ MACKOVÁ, Adéla (eds.). Etnologie v zúženém prostoru. Praha: Etnologický ústav AV ČR, 2016 s. 367, 368, 372.

13 SOUČEK, Jan a MÁČEL, Otakar. Od myšlenky k realizaci expozice lidových zemědělských staveb ve Strážnici. Národopisné aktuality, 1974, 11, č. 1, s. 35.

14 Např. ŠTĚPÁN, Luděk. Začátky souboru lidových staveb Vysočina (do roku 1981). In: KR̆IVANOVÁ, Magda a KRAMPEROVÁ, Jana (eds.). 30 let souboru lidových staveb Vysočina: 1972-2002. Pardubice: Státní památkový ústav - Soubor lidových staveb Vysočina, 2002, s. 21.

15 Např. ŠTĔPÁN, Luděk. Metodická pomoc Valašského muzea $v$ prírodě $v$ začátcích Souboru lidových staveb Vysočina. Museum vivum, 2013, 9, s. 33-34; LANGER, Jiří. Luděk Štěpán odešel. Museum vivum, 2017, XII s. 140-141. 
16 LANGER, Jiří a ŠTIKA, Jaroslav. Československá muzea v prírodě. Martin: Osveta,

1989 , s. $25-26$.

17 LANGER, Jiří a SOUČEK, Jan. Problémy rozvoje muzeí v prrírodě v Československu. Národopisné aktuality, 1980, 17, č. 1, s. 2.

18 LANGER, Jiří a SOUČEK, Jan. Problémy rozvoje muzeí $v$ prírodě $v$ Československu. Národopisné aktuality, 1980, 17, č. 1 , s. 3.

19 LANGER, Jiří. Úspěchy a prohry Valašského muzea $\checkmark$ prírodè. Museum vivum,

2014/2015, 10, s. 74-84;

ŠTËPÁNEK, Ladislav. K problematice a formám národopisných muzeí v prírodě Středočeského kraje. Národopisné aktuality, 1971, 8, s. 75.

20 ŠTIKA, Jaroslav. Idea Valašského muzea $v$ prírodě, její vývoj a proměny. In: Almanach $k$ 75. výročí založení Valašského muzea v prírodě v Rožnově pod Radhoštěm.

Rožnov pod Radhoštěm: Valašské muzeum $v$ prírodě, 2000 , s. $16-19$.

21 RISLLINK, Vladimír a PŘENOSILOVÁ, Dana. Kouřimský skanzen od založení k dnešku. Museum vivum, 2010, 6, suplementum, s. 83-85; ŠTËPÁNEK, Ladislav. K ochraně lidových staveb $v$ muzeích $v$ prírodě. Národopisné aktuality, 1968, 5, c.. 3-4, s. 277-279.

22 ŠTËPÁNEK, Ladislav. $K$ problematice a formám národopisných muzeí v príirodě Středočeského kraje. Národopisné aktuality, 1971, 8, č. 1 , s. 74 . pro záchranu staveb, ${ }^{16}$ jak později doložili naši přední tvůrci muzeí v přírodě Jiří Langer a Jan Souček: "Počátek budování československých muzeí v př́rodě vyvolal poměrně ostrou polemiku mezi zastánci tradičního zpiosobu ochrany in situ - soliterü, souborů, či památkových rezervací a propagátory výstavby specializovaných muzeí v prírodè, používajících tehdy transferu, tvorby rekonstrukcí a kopií jako rozhodující metody práce. Polemika ze strany památkové péče byla téměr výhradně zaměrena $k$ pojetí zpưsobu záchrany staveb, př́čemž uchování pưvodní hmoty a formy každého objektu bylo v šedesátých letech rozhodujicím měřitkem hodnocení kvality vznikajících muzeí v přirodě. Ve všech materiálech formulovaných památkovou péči k záchraně objektů lidového stavitelství je sice uvedena zmínka, že architektura vyjadřuje zpưsob života lidu, ovšem žádný z těchto dokumentů již nekonkretizuje, jak bude život lidu zachycen v komplexním modelu. Většina tehdejších teoretických památkových prací absolutizovala architektonické proky a vytvářela formální typologie, ale bez dostatečného ohledu na všechny di̊ležité funkce stavitelství $v$ životě lidu, a dokumenty především pomíjely rozhodující hospodárské i sociální funkční závislosti." 17 Hlavní smysl muzeí v přírodě a ideál, kterého se většina těchto muzeí v období jejich vzniku a rozvoje snažila dosáhnout, vystihli Jiří Langer s Janem Součkem: "Pro muzejní př́stup není vủbec rozhodující použitý způsob ochrany (in situ, převoz), ale proořadý je sledovaný cíl - vytvořní komplexního modelu životního prostředí, s maximálně dostupnou informační hodnotou, byt' by to bylo dosaženo zpưsobem uchování na pưvodním místě. "18

Cílem památkářo̊ a muzejníků bylo od 60. let 20. století původně zachraňovat originální stavby, přičemž podíl autentických památek i jejich jednotlivých prvků byl v tomto období ve srovnání s pozdějším obdobím a zejména dneškem ještě relativně vysoký. Zároveň byli přítomni řemeslníci znalí tradičních postupů, navíc omezeni ekonomickými podmínkami muzeí na tehdy již doznívající ruční práci. Můžeme také tvrdit, že přes prezentované reálie muzea $\mathrm{v}$ př́rodě unikla tomu, aby se stala ve větší míre nástrojem dobové propagandy. Jednalo se o vysoce odbornou, ale také nadšeneckou aktivitu, která byla díky svému obsahu alespoň podle možností v hodnotovém žebříčku tehdejší společnosti podporována př́íslušnými orgány. ${ }^{19}$

Od 60. let 20. století tedy vznikala muzea $\mathrm{v}$ přírodě jako prostředí určené primárně pro záchranu ohrožených staveb, tak jako počáteční koncepce dostavby vesnické části v Rožnově před rokem $1965 .{ }^{20}$ Obdobně můžeme sledovat další záchranné aktivity zvláště ve Středočeském kraji. Primárně záchranný účel mělo muzeum v Kouřimi, odkud měly být pưvodně odložené stavby následně přeneseny do plánovaného muzea $\mathrm{v}$ pražské Šárce. ${ }^{21}$ Stejně tak se vyznačovalo nejprve záchranným charakterem muzeum v Přerově nad Labem.

Problémy při budování záchranných muzeí právě ve Středočeském kraji na počátku 70. let popsal památkář a architekt Ladislav Štěpánek: "Nemůžeme také získat stavbu, kterou nám vlastník neprodá. Takovou můžeme jen zdokumentovat a rekonstruovat $z$ nového materiálu. To však odporuje zásadě záchranného zařízení i názoru některých památkářu. V Středočeském kraji se brzy začaly domy zdit, proto jejich zařizení do muzea je možné jen rekonstrukcí, anebo vybudováním muzea u takového objektu. Zdálo by se proto, že forma záchranného zařízení budování muzea značně ztěžuje. " 22

Tomuto esenciálnímu a na první pohled protikladnému vztahu snahy o záchranu materie a muzejního využití včetně možností jejich kreativní symbiózy se v jednom $\mathrm{z}$ textů věnoval tehdejší pracovník Valašského muzea v př́rodě, historik Petr Šuleř: "Oslabení autenticity objektu se nepř́iznivě obráží $i$ ve stavu identity, a oslabením či neuplatňováním hledisek identity se nemohou uplatnit hodnoty autenticity objektu. Závažným problémem je v této souvislosti otázka kopií a rekonstrukcí. Zdánlivě každé uplatnění těchto technik snižuje autenticitu objektu při snaze o zoýšení identity. To je však pouze zdánlivá ztráta. Vždyt’ náhrada zničených či chybějících prokư müže pouze zoýšit autenticitu objektu, jakkoliv se zde uplatňují i nové techniky a materiály. Mimořádně 
citlivou oblastí je ovšem míra těchto zásahů. Při úplné kopii nebo rekonstrukci je pochopitelně autenticita velmi nízká a musíme přikročit k takovým zásahưm, aby systém byl alespoň částečně stabilní (konzervace, bareoné úpravy, doplňování autentickými detaily). Obecně lze říci, že uplatnění kopií a rekonstrukcí je vždy $v$ zájmu posílení identity předmětu, přičemž je nutno plně respektovat požadavek neporušení autenticity objektu. A současně, plné využití autenticity objektu, jeho maximální respektování a emotivní využití, je ideálním podkladem pro stanovení identity. “23

Konfrontace obou pojetí je v některých případech patrná až do současnosti a jistě záleží na konkrétním případu, k jaké cestě se přiklonit. Patrně také na základě těchto prvotních neshod se snaha o záchranu materie a snaha o tvorbu komplexního prostředí neděla $\mathrm{v}$ potřebné symbióze. $S$ rozvojem muzeí v prrírodě se postupně začalo prosazovat i jejich komplexní pojetí prostředí. Již v záchranné epoše byla taková cesta patrná ve Valašském muzeu $\mathrm{v}$ přírodě, a to zejména prostřednictvím osobnosti ředitele Jana Rudolfa Bečáka. Dodržení historického urbanismu prosazoval také autor koncepcí středočeských muzeí Ladislav Štěpánek. Zcela přirozeně byla díky terénním znalostem a tvưrčímu talentu Lud'ka Štěpána při tvorbě souboru lidových staveb na Veselém Kopci respektována rozptýlená zástavba.

Postupné prosazování muzejnického přístupu při tvorbě muzeí v přírodě vneslo do jejich pojetí zároveň s opouštěním primárně záchranného principu tvorbu kopií a rekonstrukcí, nyní již s obhájením odbornou a naučnou funkcí komplexní prezentace. Zatímco při dostavbě Valašského muzea v př́rodě byla během 60. let nejprve patrná výhradně snaha o záchranu originálních objektů, tak v 70.-80. letech však $\mathrm{z}$ důvodu snahy o komplexnost stavebních forem převyšovaly záchranu objektů kopie a rekonstrukce. Stavby vybrané starší koncepcí, v terénu již zaniklé, značně poškozeny nebo nedostupné $\mathrm{z}$ majetkových důvodů tak byly pro expozici nahrazovány kopiemi. Novostavby jsou už po desetiletí doménou také dalších muzeí v prírodě.

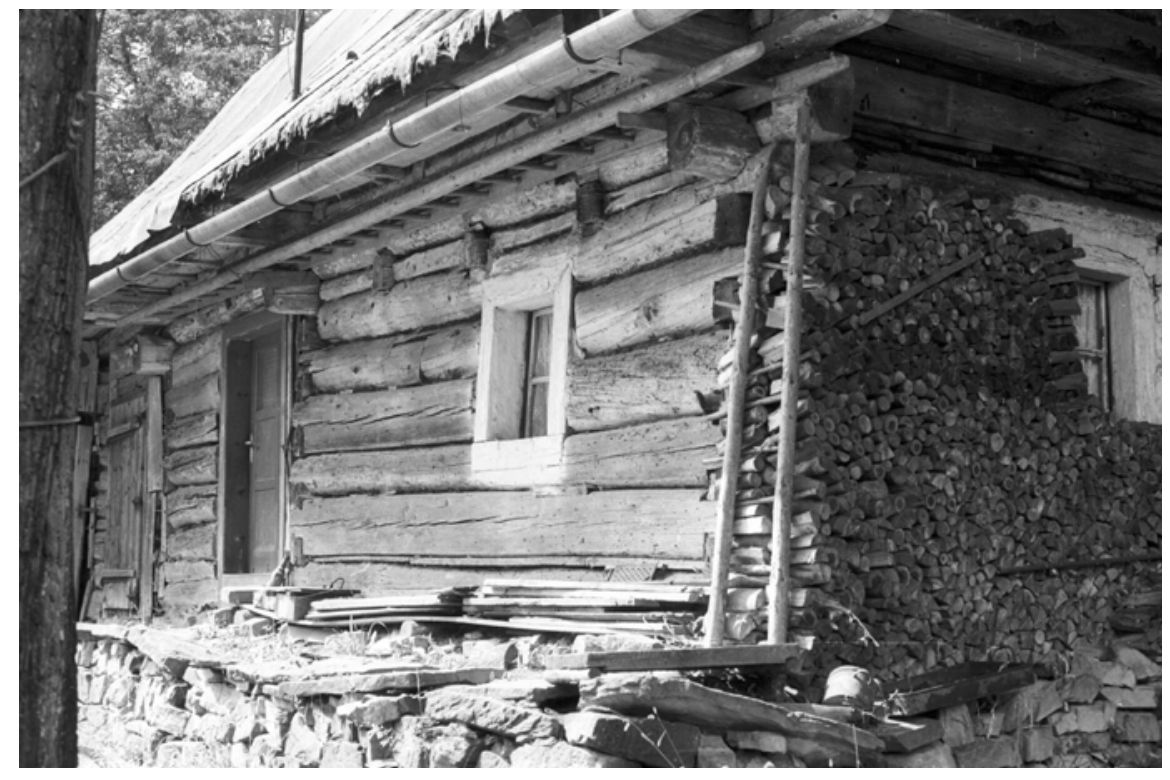

\section{Kdo muzea postaví?}

Snaha o nalezení optimálního přístupu k záchraně stavebních památek v muzeích v prrírodě je od konce 50 . let 20. století patrná nejen $\mathrm{v}$ teoretické rovině při tvorbě koncepcí, ale také při konkrétním zacházení s historickou materií. Ve Valašském muzeu vzniklo jen pro Valašskou dědinu mezi lety 1955 a 1974 několik koncepcí celkového rozvoje areálu, až se ustálily v roce 1974. Zároveň byl hledán zpơsob vhodného transferu či konzervace staveb. ${ }^{24}$

Pro realizaci dostavby rožnovského muzea byla vybrána tesařská skupina, která původně fungovala jako přidružená výroba tamního JZD zvláště za účelem výroby šindelů a oprav střech na památkách. Až později vznikla prímo $v$ muzeu tesařská četa, přičemž určitý čas obě skupiny pracovaly paralelně. V Beskydech a jejich podhůří bývalo stále ještě v tomto období běžné, ač již v poslední fázi, například ruční tesání, které bylo v případě krovů na rodinné novostavby rozšířené až do počátku 2. poloviny 20. století, což bylo uplatnitelné také v muzeu. Jako důležitý moment tehdejšího přístupu k muzejním stavbám cítíme při omezeném finančním zabezpečení také provizornost zázemí i získávání materiálů. ${ }^{25}$ Také proto se $\mathrm{v}$ tomto období udržovala ruční práce či recyklace materiálů z jiných staveb, což velmi napomáhalo výsledné autenticitě objektů.

Přesto byla situace s vhodnými řemeslníky a výslednou kvalitou práce velmi problematická, jak uváděli představitelé tehdejších muzeí, včetně rožnovského. ${ }^{26}$ Situaci ve Středočeském kraji již před půlstoletím zmínil Ladislav Štěpánek:
Mnohé stavby měly pred realizací v muzeu řadu charakteristických detailů, foto Jiři Langer, 1980 (Oddělení dokumentace VMP, NMvP)

23 ŠULĚ̆, Petr. Autenticita identita, aneb o potrebě užitečného napětí. Národopisné aktuality, 1980, 17, č. 1. s. 74 24 BRYOL, Radek. Devadesát let transferů do Valašského muzea $v$ prírodě $v$ Rožnově pod Radhoštěm. In: Transfer a rekonstrukce památek lidové architektury. Rožnov pod Radhoštěm - Sebranice: Valašské muzeum v prírodě Spolek archaických nadšenců, 2016, s. 21.

25 VRLOVÁ, Vanda. Miloňov $v$ rožnovském muzeu už 55 let. Valašsko, vlastivědná revue, 2018,41 , c. 2, s. 30-31; BRYOL, Radek. Devadesát let transferů do Valašského muzea $v$ prírodě $v$ Rožnově pod Radhoštěm. In: Transfer a rekonstrukce památek lidové architektury. Rožnov pod Radhoštěm - Sebranice: Valašské muzeum v prírodě Spolek archaických nadšenců, 2016, s. 22.

26 BRYOL, Radek. Devadesát let transferů do Valašského muzea $v$ prírodě v Rožnově pod Radhoštěm. In: Transfer a rekonstrukce památek lidové architektury. Rožnov pod Radhoštěm - Sebranice: Valašské muzeum v prírodě Spolek archaických nadšenců, 2016, s. 24-25. 
27 ŠTĚPÁNEK, Ladislav. $K$ problematice a formám národopisných muzeí v prírodě Středočeského kraje. Národopisné aktuality, 1971, 8, č. 1 , s. 74 .

28 ŠTĚPÁNEK, Ladislav. $K$ problematice a formám národopisných muzeí v prírodě Středočeského kraje. Národopisné aktuality, 1971, 8, c. 1 , s. 75 .

29 Na výstavbě muzea $v$ roce 1972 trvaleji bylo činno 22 pracovníků, kromě velmi četných dočasných. Viz ŠTĚPÁNEK, Ladislav. Třebíz - muzeum sociálního rozvrstvení vesnice. Národopisné aktuality, 1975,

12 , č. 1, s. 79.

30 ŠTĚPÁN, Luděk. 15 let Souboru lidových staveb a řemesel Vysočina. Památky a príroda, 1987, 47, s. 217-220. 31 ŠTËPÁN, Luděk. Soubor lidových staveb Vysočina Dvacet let od zprístupnění prvního objektu. Zprávy památkové péče, 1992, 52, č. 8, s. 21.

32 SOUČEK, Jan a MÁČEL, Otakar. Od myšlenky k realizaci expozice lidových zemědělských staveb ve Strážnici. Národopisné aktuality, 1974,

11 , c.. 1 , s. 52

33 SOUČEK, Jan a MÁČEL, Otakar. Od myšlenky k realizaci expozice lidových zemědělských staveb ve Strážnici. Národopisné aktuality, 1974,

11 , c. 1 , s. 48.

34 VAR̆EKA, Josef - Frolec, Václav. Lidová architektura.

Encyklopedie. Praha: Grada, 2007. s. 171; TICHÁ, Jana. Řezbár a mistr tesař lidových staveb Michal Žitník. Museum vivum, 2014/2015, 10, s. $185-187$.

35 LANGER, Jiří. Generační aspekt prezentace lidové výroby $v$ muzeích $v$ prírodě. In: Lidová výroba. Její dokumentace a prezentace. Vsetín: Okresní vlastivědné muzeum,

1995, s. 4-5.

36 ŠTĚPÁNEK, Ladislav. Trebíz - muzeum sociálního rozvrstvení vesnice. Národopisné aktuality, 1975, 12 , č. 1 , s. 79.
"Stavební podniky naše práce nepřevezmou, vlastní hut' nemáme, a tak se musíme spokojit s dưchodci tesaři a zedníky z místa, pokud nemají právě mnohem výnosnější práci. Ani opatřování materiálu (i lomového kamene) není vždy snadné, a to pracujeme s materiály, které se již nevyrábějí v našem kraji (např. došek, štípané dřevo atd.). Za těchto podminek nemüže všude kvalita práce splňovat naše nároky a v lecčems musíme slevit."27 Autor článku oceňoval pochopení příslušných institucí a orgánů i místních občanů, kteří se na realizaci podíleli: "Zvláštní dík pak patři staviteli Janu Nedvědovi, nadšenému památkáři, který s neobvyklou obětavostí řídi práce v Třebízi. Jen díky této spolupráci můžeme vzdor všem výšeuvedeným obtížim postupovat, $i$ když ne všude tak, jak bychom si přáli. Pro některé významné lidové stavby Středočeského kraje již však bije hodina dvanáctá, a proto musíme jednat tak, jak je možné. "28 V Třebízi byla navíc $\mathrm{k}$ dispozici dobře vybavená kovářská a truhlářská dílna, příslušející k tamnímu MNV. ${ }^{29}$

Významným počinem nejen za účelem zachování architektonického dědictví, ale také znalostí spjatých s řemeslem byly od poloviny 60 . let 20 . století aktivity kolem vzniku expozice lidového stavitelství na Veselém Kopci. Jejím iniciátorem byl původně technik silničních staveb Luděk Štěpán. Jemu se podařilo z pozice konzervátora památkové péče, ale zejména nad rámec zaměstnání zdokumentovat a zachránit řadu venkovských staveb, ale také sestavit zprvu převážně dobrovolnickou skupinu, která se na transferech a rekonstrukcích podílela. Záchrana tradičních technologií v tomto př́padě vygradovala ve vznik specializovaných skupin sekerníků pod vedením Jiřího Myšky a Pavla Tomáška a bez přímého vlivu vznikajícího muzea na Vysočině také např́iklad skupiny Františka Mikyšky. Tito odborníci se podíleli na projekci a obnově řady historických technologických zařízení $\mathrm{v}$ naší zemi i zahraničí. ${ }^{30}$

Právě Luděk Štěpán připomněl, jak probíhala záchrana prvních objektů. "Zdarma se prováděl jejich historický, architektonický a etnografický prízkum, řizení organizace a stavební dozor, většina pomocných stavebních prací $i$ některé odborné stavební práce. Jen část prací se dařilo zajištovat dodavatelsky organizacemi DOS MNV Horní Bradlo, JZD Vysočina, n. p. Silnice - provoz Hlinsko, OPOS - zakázkové truhlářství Hlinsko a Družstvo invalidu Proseč (šindelové krytiny)." Zkušenosti nejen z tvorby této expozice prokázaly smysluplnost zkombinování staveb in situ s transfery. Přesto také tvorba této expozice dokázala, přes vysoké kvality zúčastněných osobností, některé problémy $\mathrm{v}$ metodice přenášení objektů, zejména $\mathrm{v}$ případě skrytých konstrukcí. ${ }^{31}$ Uspěchy spjaté se vznikem expozice na Veselém Kopci daly na přelomu 80. a 90. let základy k záchraně souboru obydlí řemeslníků v hlineckém Betlémě. Pro výstavbu se tedy v jednotlivých vznikajících muzeích podařilo získat kapacity včetně nadšenců různých kvalit. $\mathrm{V}$ případě počátků muzea $\mathrm{v}$ př́rodě ve Strážnici byly stavební činnosti prováděny pracovníky okolních JZD zejména Strážnice a Lipov, avšak bylo nutné vytvoření $\mathrm{i}$ „specializované pracovní čety, jak ji ústav nárokuje. Jednotliví dodavatelé vyvíjejí maximální snahu, ale při nejlepší vuili není v jejich možnostech zcela uspokojit naše požadavky, zejména při úzce specializovaných řemeslných pracích památkového charakteru. Ústav musí mít vlastní kádr kvalifikovaných pracovníku podrobně seznámených s celou problematikou a provádějících nejnáročnější práce. Je nutno již nyní plánovat i provádění údržby rovněž velmi náročné na kvalitu práce. "32

Na jihovýchodní Moravě byla na rozdíl od uvedených muzeí situace navíc zkomplikována převahou tradičních staveb z hlíny: "Velmi vážným problémem, který jsme nuceni obdobně jako mnohé další řešit experimentálně, je technika převozu a př́padná rekonstrukce objektů z dusané hlíny nebo nepálených cihel, kterých bude v expozici nadpoloviční většina. I když je transfer i mnoha větších objektů již technicky vyřešen a ověřen, není použití tohoto způsobu z finančních a technických diovodů u mnoha staveb možné. Převoz celých objektů na trajlerech je finančně únosný pouze za optimálních předpokladů. $S$ transportem staveb z těžko př́stupných míst s nerovným terénem nelze počitat, a proto hledáme jiná východiska. "33 
Velký př́nos toho, že se v některých oblastech podařilo najít staré řemeslníky, je samozřejmý. Vždyt' někteří byli narozeni na přelomu 19. a 20. století a mohli tak zažít ještě stavební praxi v období okolo první světové války. ${ }^{34}$ Generační proměna př́stupu $\mathrm{k}$ řemeslu ve stavebních technologiích je však důležitým faktorem, který ovlivňuje výslednou podobu památky. To doložil na př́kladu práce ve Valašském muzeu již z počátků jeho dostavby v 60 . letech 20. století Jiř́ Langer: „Kde je to pravé jádro, která nás spojuje s kulturou předcházejících generací? Kde jsou ty hranice a pomezi kulturní, nikoliv jen estetické kvality jevio? (...) Jen my muzejníci - vzpominajice na to, jak vypadaly naše expoziční objekty na pưvodním mistě - pocitujeme kromě úcty $k$ osobnostem těchto řemeslníkư někdy i lehké mrazení. Jistěže přesná dokumentace by měla zajistit, že řemeslníci podle ní postaví přesnou kopii. (...) Přece si ale uvědomujeme generační rozdíly napríklad u tesařu, jak chápou své poslání, jaké mají představy o dokonalosti výsledku své práce." ${ }^{135}$

Některé vzácné prvky byly z různých důvodů pro docílení kompaktnosti během rekonstrukce marginalizovány, tak jako malovaný strop v komoře Cífkova statku v Třebízi: „Z toho se však dochoval jen fragment, který podle doc. V. Pražáka je nejcennějším reliktem objektu. Na př́ní ÚSPPOP byl však podbit a omitnut. ${ }^{\text {36 }}$ Ve Valašském muzeu $\mathrm{v}$ př́rodě byla naopak řada prvků uváděna do typické podoby - stavěly se kamenné komíny a zápraží, stavby byly kryty výhradně šindeli, přestože předloha, a to nejen $\mathrm{v}$ prípadě mladších úprav, byla jiná. ${ }^{37}$ Problematické byly i zákroky na dalších památných venkovských stavbách, jako fatální porušení původního stavu, ponechání trouchnivých trámů v konstrukci atd., jak uvedl Miroslav Válka $\mathrm{v}$ př́ípadě rekonstrukce větrného mlýna ve Velkých Těšanech na Kroměřížsku. ${ }^{38}$

\section{Konstruktivní kritika?}

$\mathrm{V}$ relativně malém okruhu muzeí $\mathrm{v}$ přírodě je v současnosti velmi problematické vedení konstruktivní kritiky. Nejvýraznější kritická diskuse $\mathrm{v}$ této oblasti probíhala

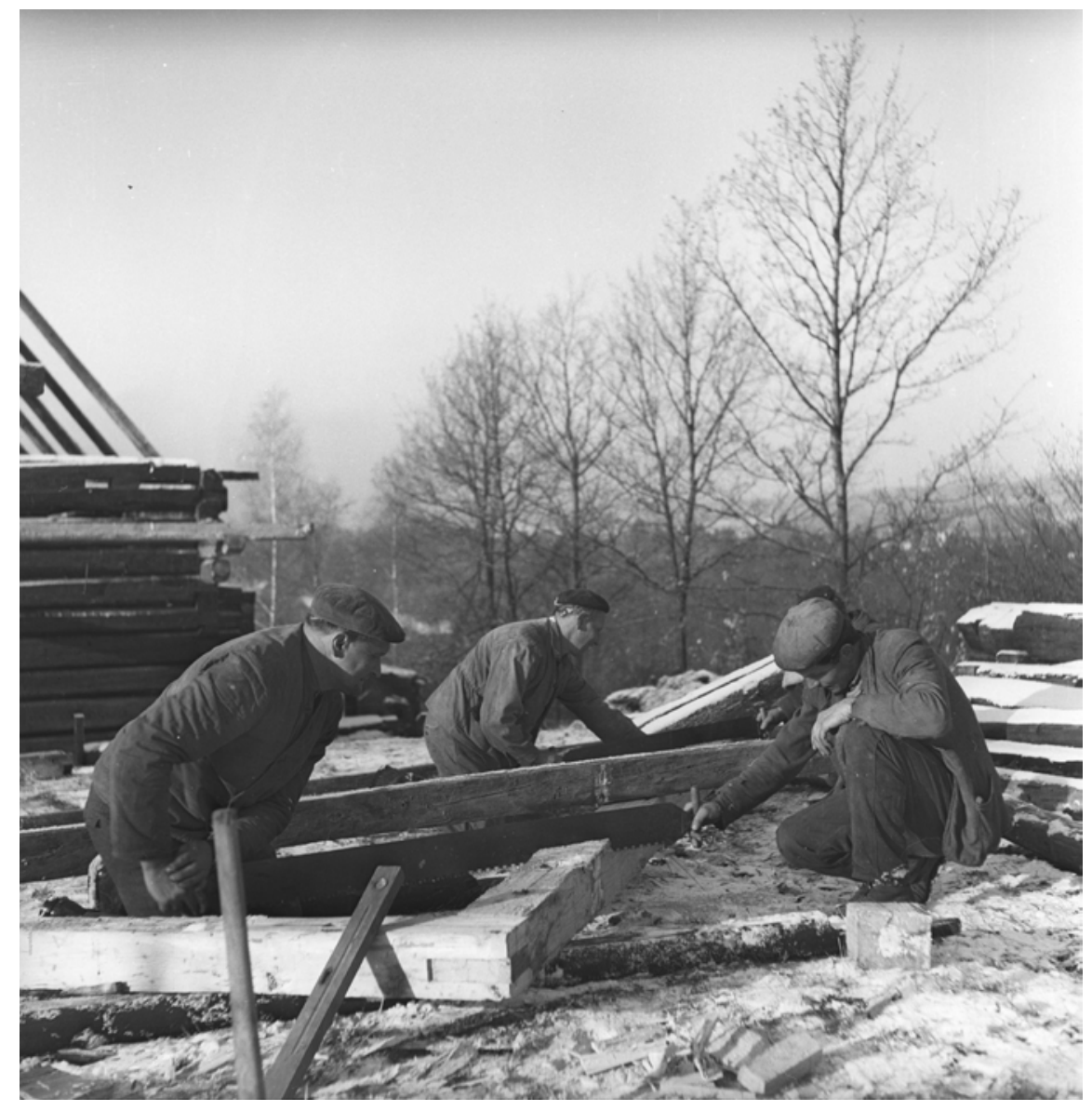

zvláště v 70. a 80 . letech 20 . století během rozvoje několika muzeí v přírodě v naší zemi. Pravidelně se uskutečňovala odborná setkáníi ${ }^{39}$ a na stránkách periodika Národopisné aktuality byla tomuto typu muzeí vyhrazena samostatná rubrika. ${ }^{40}$ Přijímat $\mathrm{i}$ vznášet kritiku není $\mathrm{v}$ této oblasti lehké z několika důvodů. Takřka za každým stavebním záměrem $\mathrm{v}$ muzeu $\mathrm{v}$ prrírodě stojí na počátku dobrý úmysl záchrana stavby nebo doplnění areálu muzea o objekt na základě platných koncepcí, často navíc vysněný již předchůdci současných muzejníků. Při následném financování často $\mathrm{z}$ různých grantových titulů či pomocí zřizovatele se instituce prostřednictvím svého vedení a odborných pracovníků zavazuje $\mathrm{k}$ naplnění vymezených cílů. Netřeba dále popisovat, jak je i s důslednou př́pravou složité předvídat nejrůznější technické problémy, které mohou nastat při samotné realizaci a v závěru se projeví na výsledné podobě stavby.

Důležitým momentem v oblasti muzeí $\mathrm{v}$ př́rodě a patrně $\mathrm{i}$ obecně $\mathrm{v}$ památkové péči je, samozřejmě s vědomím rozdílných př́stupů také v těchto specializacích, jakési semknutí - MY jako zachránci těch posledních památkových a historických
Počátky většiny našich muzeí v přirodě byly ovlivněny nelehkou situací, stavba první chalupy na Valašské dědině v Rožnově, foto Vanda Bulavová, 1962 (Oddělení dokumentace VMP, NMvP)

37 BRYOL, Radek. Devadesát let transferů do Valašského muzea $v$ prírodě $v$ Rožnově pod Radhoštěm. In: Transfer a rekonstrukce památek lidové architektury. Rožnov pod Radhoštěm - Sebranice: Valašské muzeum v prírodě Spolek archaických nadšenců, 2016, s. 23-25.

38 VÁLKA, Miroslav. Větrný mlýn ve Velkých Těšanech obnoven. Národopisné aktuality, 1980,17 , č. 1, s. 75.

39 Zejména rožnovské konference Museum vivum a Agricultura carpatica. 40 DRÁPALA, Daniel a NOSKOVÁ, Jana. Bibliografie Národopisných aktualit 19641990. Strážnice: Národní ústav lidové kultury, 2003; Z článků např. JER̆ÁBEK, Richard. Výtvarný zřetel $v$ budování národopisných muzeí v prírodě. Národopisné aktuality, 1976, 13 , s. 211-216. 


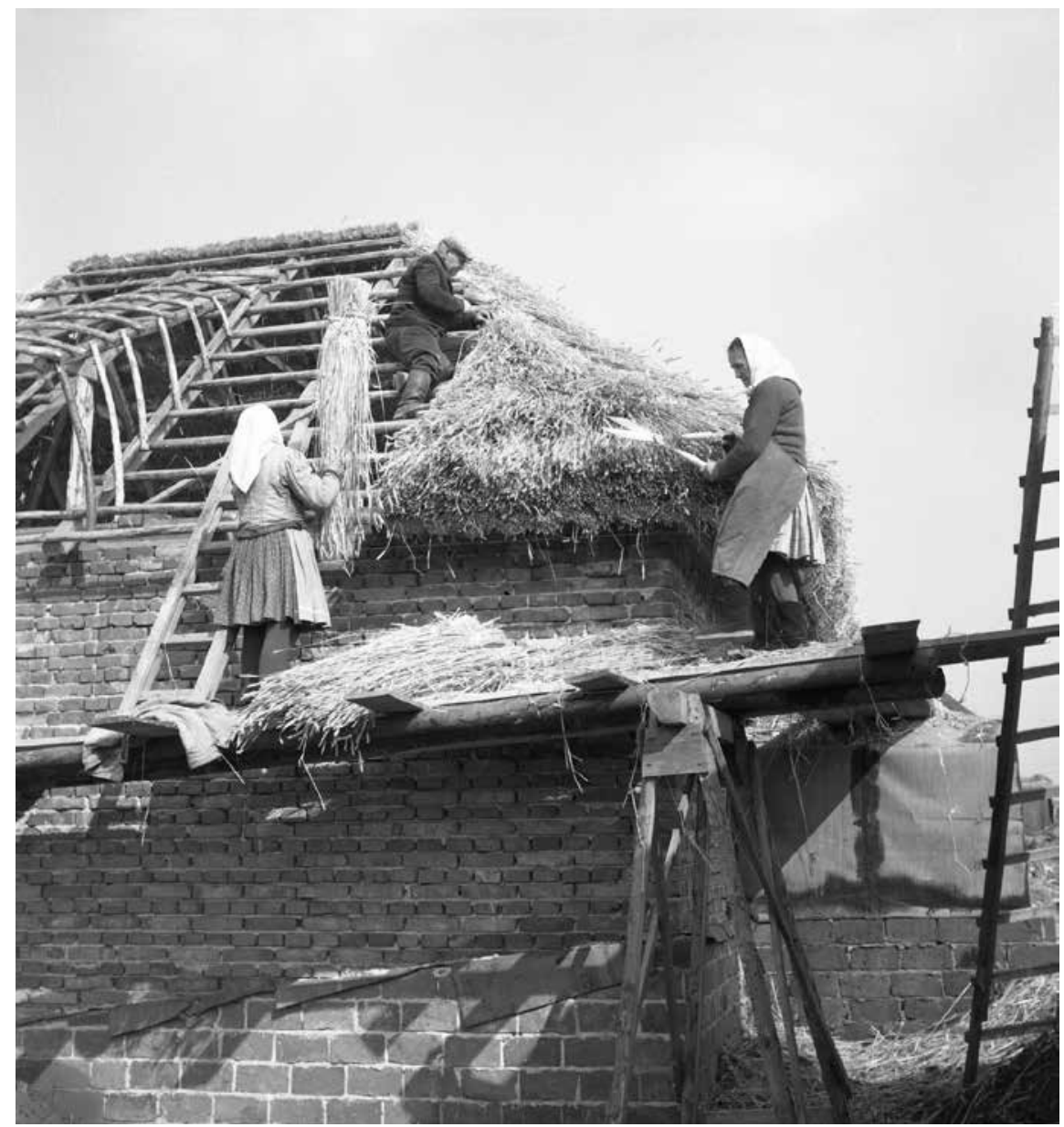

Pracovníci JZD Lipov při pošivání střechy došky $v$ muzeu $v$ prírodè ve Strážnici, foto Josef Jančář, 1975 (Fotoarchiv NÚLK Strážnice)

41 Tak jako v prípadě domu z Dolního Újezda, viz KR̆IVANOVÁ, Magda.

Soubor lidových staveb Vysočina v letech 1981-1997.

In: Ǩ̆IVANOVÁ, Magda a KRAMPEROVÁ, Jana (eds.).

30 let souboru lidových staveb Vysočina: 1972-2002.

Pardubice: Státní památkový ústav - Soubor lidových staveb Vysočina, 2002, s. 29.

42 Např. MICHALIČKA, Václav. Některé aspekty revitalizace tradičních technologií lidové-

ho stavitelství. Národopisná revue, 2010, 20, s. 79-83; Také např. ABUŠıNOV, Roman. Dostavba skanzenu v Přerově nad Labem. Dostupné z: http:// www.roman-abusinov.czl, cit.

18. 5. 2020.

43 Kauza PhDr. Jiří Langer, CSc. vs. Valašské muzeum $v$ prírodě $v$ Rožnově pod Radhoštěm. Dostupné $z$ : http://www.narodopisnaspolecnost.cz/old/kauza.php, cit. 20. 5. 2020. hodnot a ONI jako většinová společnost, která tyto hodnoty zpravidla nectí nebo jim nerozumí. Celý problém posilují ještě nejrůznější zištné zájmy a také omezené vnímání estetiky ze strany většinové společnosti, která jako památky toleruje snad jen líbivé objekty ve skanzenech nebo podhorské chaloupky se zavěšenými koly žebřiňáků. A proti tomu všemu stojí nebohý muzejník či památkář...

Také sebekritika je $\mathrm{v}$ muzeích $\mathrm{v}$ přírodě patrná spíše výjimečně. ${ }^{41}$ I konstruktivní kritika může být nejen $\mathrm{z}$ těchto důvodů vnímána jako útok na konkrétní osoby notlivci se pak i přes své renomé či odbornost dostávají do role záškodníků neloajálních vưči předním kulturním zařízením v naší zemi. ${ }^{42}$ Bez větší odezvy zůstaly například připomínky Jiřího Langra na realizace staveb ve Valašském muzeu v přírodě v rámci Norských grantů 2000-2010. Samozřejmá byla v tomto záměru snaha muzea o naplnění koncepce navíc $\mathrm{v}$ souladu se záměry samotného Jiřího Langra. Avšak zejména konstrukční provedení staveb vykazovalo různé chyby způsobené jak neznalostí řemeslníků a projekce, tak personální výměnou $\mathrm{v}$ muzeu. ${ }^{43}$ a na kritizované instituce. Kritizující jed-
V přístupu k historickým objektům v našich muzeích v přírodě je patrných několik zásadních problémů. Jako hlavní můžeme označit přílišné vyměňování poškozených konstrukcí bez náležité analýzy, kde hlavní negativní roli hraje pokřivená estetika a alibistická snaha o zvýšení bezpečnosti. Naše památky pak někdy opouštějí zejména dřevěné konstrukční prvky, které jsou pouze povrchově poškozeny, přičemž jsou často nahrazeny navíc méně kvalitním současným dřevem. $\mathrm{V}$ případě výměn není dbáno ani na výběr materiálu - charakteristická příprava, druh, profil, opracování, detaily konstrukce a zpracování, spojovací prvky atd.

$\mathrm{V}$ naší zemi se stalo normou např́íklad jakési fingování historického opracování tesáním, kdy je bez původní podstaty štípání po vláknech dřeva povrch předřezaného profilu jaksi rustikálně nafingován. Právě s poznáním trasologie je výsledek takového prrístupu v hrubém nesouladu. Mylné evolucionistické myšlení tak nepřirozeně navrací moderní ideálně rovný strojem provedený řezaný povrch do vývojově nižšího stupně hrubě a neuměle provedeného ručního tesání.

Např́klad ve Valašském muzeu v přírodě, které je předním muzeem tohoto typu v naší zemi s velmi dobrým zázemím, pokračoval v 90. letech trend tvorby kopií a rekonstrukcí na úkor přenášení originálních objektů, což se dělo i nadále při rozsáhlé externí výstavbě v rámci Norských grantů. Jedinou z mála možností, kdy se kromě četné údržby mohli muzejní řemeslníci důkladněji setkat s originální historickou architekturou, byl transfer seníku z Nového Hrozenkova. ${ }^{44} \mathrm{~V}$ posledním období se může řemeslná práce rozvíjet při transferech pro Valašskou dědinu a nový areál Kolibiska. Otázkou zůstává, zda může být taková fatální diskontinuita mezi osmdesátými lety minulého století a nedávnou současností překonána?

Použití řady moderních materiálů bylo kritizováno např́klad v Muzeu lidových staveb v Kouřimi, ale jedná se o problém charakteristický pro řadu dalších institucí, včetně památek slohové architektury: 
„Exteriér objektu byl pozměněn nejen nahrazením eternitu dřevěnými šindeli, ale hlavně povrchovou úpravou stěn, které jsou $z$ nevhodně opracovaných trámů ošetřených hnědými lazurními nátěry několika odstínů. Spáry mezi trámy byly natřeny modrým primalexem a pro výzdobu štítu byly zvolené výrazné netradiční barvy. Př́chod k objektu vede po vybetonovaném zápraží kolem stěny izolované lepenkou, jež nebyla zarovnána s roubením a její okraj je tak dobře viditelný. Roubení této stěny poškozené tesaříkem bylo opraveno žlutou montážní pěnou a přetřeno hnědým nátěrem do barvy trámù, následně však byla pěna poškozena hmyzem a tak je tento zpưsob obnovy neprehlédnutelný." 45

Problémem je $\mathrm{v}$ těchto případech samozřejmě dostupnost odborníků a kvalifikace řemeslníků. Vážným faktorem je $\mathrm{v}$ muzeích $\mathrm{v}$ př́rodě právě komplexnost jejich expozic, jejichž preciznost je podmíněna znalostmi řady oborů. Početně malé odborné zázemí většiny muzeí tak se snahou při preferenci jiných oblastí prezentace nedokáže dohlédnout či koordinovat stavební aktivity, které vyžadují rovněž komplexní znalosti několika disciplín. V muzeích s větším zázemím jsou problémy jiné, jako například nedůvěra v tradiční postupy, zpưsobená mimo jiné uvedenou diskontinuitou.

\section{Než zmizí poslední památka}

$\mathrm{Na}$ konci příspěvku přinášíme alespoň vybrané př́klady různých metod, $\mathrm{z}$ nichž každá má přes svou odlišnost určité opodstatnění a může při své aplikaci vést k zlepšení přístupu $\mathrm{k}$ památkám $\mathrm{v}$ našich muzeích $\mathrm{v}$ přírodě.

Základem přípravy stavebních akcí by mělo být pečlivé shromáždění příslušných informací, které je v rámci stavebně historického průzkumu pravidlem v památkové péči, ${ }^{46}$ ale $\mathrm{v}$ muzeích $\mathrm{v}$ přírodě často chybí. Citlivým př́stupưm $\mathrm{k}$ památkám se v poslední době věnují některé technické obory. $\mathrm{K}$ jejich metodám řadíme nové metody, např́klad diagnostiku dřevěných konstrukcí. ${ }^{47} \mathrm{Na}$ obdivuhodném pomezí řemeslné zkušenosti, poznání historických konstrukcí i historických pramenů stojí trasologie opracování dřevěných konstrukcí. ${ }^{48}$

V praktickém provedení transferů či staveb in situ je pak nejdůležitější snaha o zachování maximálního počtu původních konstrukcí nebo $\mathrm{v}$ případě nemožnosti zachování snaha o co nejpravdivější rekonstrukci, a to jak technologicky, tak vizuálně. Za zmínku v tomto kontextu stojí citlivý přístup ke stavbám v Muzeu vesnických staveb středního Povltaví na Vysokém Chlumci, kde je výsledek podařenou souhrou odborného vedení, technické projekce i dodavatele stavebních prací. V případě Muzea vesnice jihovýchodní Moravy ve Strážnici je třeba připomenout mezioborový výzkum hliněného stavitelství a jeho aplikaci na objektech v expozici. ${ }^{49}$

Možnou cestou zachování autentických detailů staveb je $\mathrm{v}$ zahraničí, zvláště $\mathrm{v}$ Německu, relativně běžná, $u$ nás naopak méně rozširrená metoda transferu celistvých dílců staveb $\mathrm{v}$ bloku. To je proveditelné zvláště u objektů zděných nebo hrázděných. V České republice v posledních dvaceti letech proběhly takové transfery právě pro muzeum v prírodě na Vysokém Chlumci (2000, 2005 - zděné klenby černých kuchyní spolu s částí komína $)^{50}$, skanzen lidové architektury pod hradem Velhartice (2007 - stěny z nepálených cihel), a později pro skanzen v Přerově nad Labem (2015 - fragmenty stěn z nepálených cihel) ${ }^{51}$ a naposledy ve Valašském muzeu v př́rodě (2017 - části kamenných stěn). Přes někdy propagované prvenství těchto činů jsou transfery celistvých staveb patrné i v minulosti našeho muzejnictví v prrírodě. ${ }^{52}$

Příkladné přístupy $\mathrm{k}$ památkám $\mathrm{v}$ muzeích $\mathrm{v}$ přírodě najdeme i $\mathrm{v}$ dalších institucích nebo $\mathrm{v}$ rámci spolkových aktivit udržujících památky vernakulární architektury. Za připomínku stojí například směřování Spolku archaických nadšenců, resp. Institutu lidového kulturního dědictví. Kolektiv nadšenců nejenže sdružuje odborníky různých oborů - architekti, řemeslníci atd., ale před započetím samotných rozsáhlejších stavebních akcí se i přes některou vnější kritiku snažili podrobit
44 TICHÁ Jana. Roubený seník s kamenným sklepem z Nového Hrozenkova Břežitá. Rekonstrukce historické podoby původního objektu pro realizaci ve Valašském muzeu v prírodě. Museum vivum, 2009, 5, s. 113-117.

45 SVOBODOVÁ, Jana.

Muzeum lidových staveb $v$ Kouřimi. Museum vivum, 2010, 6, suplementum, s. 98. 46 BLÁHA, Jiří a kol.

Operativní průzkum a dokumentace historických staveb. Praha: Národní památkový ústav, 2005; PODROUŽEK,

Kamil a kol. Metodika dokumentace lidové architektury. Ústí nad Labem: Národní památkový ústav - Filozofická fakulta univerzity J. E. Purkyně, 2015 aj.

47 KLOIBER, Michal

a DRDÁCKÝ, Miloš. Diagnostika dřevěných konstrukcí. Praha:

ČKAIT, 2015.

48 Např. BLÁHA, Jiří a RŨŽIČKA, Petr. Trasologický rozbor dřevěných prvků roubené polygonální stodoly usedlosti čp. 97 v Čisté. In: Průzkum a dokumentace památek lidové architektury. Rožnov pod Radhoštěm - Sebranice: Valašské muzeum v prírodě Spolek archaických nadšenců, 2016, s. 174-189.

49 NOVOTNÝ, Martin. Hliněné stavitelství na Moravě a evropské souvislosti. Kritický katalog k výstavě. Strážnice: Národní ústav lidové kultury, 2014. 50 PROCHÁZKA, Lubomír. Transfer klenby černé kuchyně obytného stavení Obděnice čp. 4 (okr. Príbram) do Muzea vesnických staveb středního Povltaví ve Vysokém Chlumci. Středočeský vlastivědný sborník. 2001, sv. 19, s. 123-125. 51 HANZLÍKOVÁ, Markéta. Transfer a následná obnova jednoho z posledních polabských domů s podsíní. In: Transfer a rekonstrukce památek lidové architektury. Rožnov pod Radhoštěm - Sebranice: Valašské muzeum v prírodě Spolek archaických nadšenců, 2016, s. 84-95.

52 Již v 70. letech 20. století byly $v$ bloku přenášeny některé roubené stavby s hliněným omazem do strážnického 
Muzea vesnice jihovýchodní Moravy. V roce 1990 byla jako součást Souboru lidové architektury v Zubrnicích úspěšně vcelku prenesena hrázděná kaple z Žichlic na Teplicku, viz SOUČEK, Jan. Stavební památky v komplexu muzejní činnosti Ústavu lidového umění ve Strážnici. Národopisné aktuality, 1976, 13, č. 3, s. 191-200. 53 Kontakt s architektem Walterem Traufferem, někdejším dlouholetým ředitelem muzea, a jeho kolegy přinesl $v$ naší praxi dosud ve větši míre nepoznaný rozměr přiznání současných stavebních zásahü na vybraných stavbách. Dřevěné prvky jsou napríklad predřezány, ale povrchová úprava je provedena hoblováním, aby se co nejvíce svým povrchem blížila tesání, ale zároveň na stavbách $z$ několika stavebních epoch odlišovala nové intervence. $\mathrm{Na}$ často $v$ profilu čtvercových či obdélníkových prvcích alpského stavitelství pưsobí takový prístup prirozeně, ale je aplikovatelný také na pritesávané prvky profilu kulatého. Paralelně s takovým prístupem se $v$ muzeu logicky snaži udržovat historické stavební technologie.

54 LEDVINKA, František. Práce s hlínou v zubrnickém skanzenu. In: VÁLKA, Miroslav

a MALACH, Roman. Vesnická stavební kultura. Stavební materiál - domová dispozice - slohové ohlasy - dřevěné sakrální stavby. Brno: Masarykova univerzita, 2014, s. 87-96; SMOLÍK, Luboš. Aktivity klatovského muzea $v$ letech 1990-2005 - expozice lidové architektury $\checkmark$ Chanovicích. Museum vivum. 2006, 2, s. 59-62. své záměry širší diskusi. Proběhlo několik odborných setkání, a zdrojem prostředků a zejména zkušeností bylo také navázání spolupráce s švýcarským muzeem v přírodě v Ballenbergu, které patří $\mathrm{k}$ předním $\mathrm{v}$ Evropě $\mathrm{z}$ hlediska př́stupu $\mathrm{k}$ historickým stavebním objektům. ${ }^{53}$

Z některých muzeí v přírodě zaujme spolupráce s dobrovolníky, přičemž v mnohých má již dlouholetou tradici. Při šetření prostředky se pod dohledem odborníka mohou tyto aktivity $\mathrm{v}$ případě některých technologií lépe koordinovat než při omezené spolupráci se stavební firmou. Aktivita dobrovolníků byla důležitá i při vzniku muzeí $\mathrm{v}$ přírodě $\mathrm{u}$ nás $\mathrm{v}$ pozdějším období, tak jako v Chanovicích nebo zvláště při pracích s hlínou, ale i dalších činnostech v Zubrnicích. ${ }^{54}$

\section{Závěrem}

Ohlédnutí za více než sto lety uplynulými v našem muzejnictví v přírodě dokládá komplikovanost celého vývoje tohoto oboru. Přes záštitu orgánů a institucí různého charakteru byly rozsáhlejší aktivity zpravidla dílem zaujatých jednotlivců a nejbližšího kolektivu, který se kolem nich vytvářel. Z dobových popisů je až nepředstavitelná reálná situace $\mathrm{v}$ této oblasti kulturního dědictví, kdy se historické objekty se ztrátou jejich funkce či překonáním standardů života stávaly rychlým tempem bezcenné. Na jedné straně stáli majitelé apelující na modernizaci či odstranění objektu, na druhé památkáři a muzejníci s omezenou personální a finanční, ale často také metodickou kapacitou ke stavebním aktivitám. Proto je i dnes s odstupem takřka půl století hoden uznání počet staveb, který se v nejaktivnějším období rozkvětu muzeí v prrírodě u nás během 60.-80. let podařilo zachránit. $\mathrm{V}$ takových podmínkách a zároveň s neexistující nebo tvořící se metodikou záchrany však zanikly mnohé konstrukční detaily, které byly v lepším případě pouze zdokumentovány.

Z období po společenských změnách $\mathrm{v}$ roce 1989 je $\mathrm{z}$ větších metodicky progresivních počinů $\mathrm{v}$ naší zemi obdivuhodná zejména aktivita Muzea vesnických

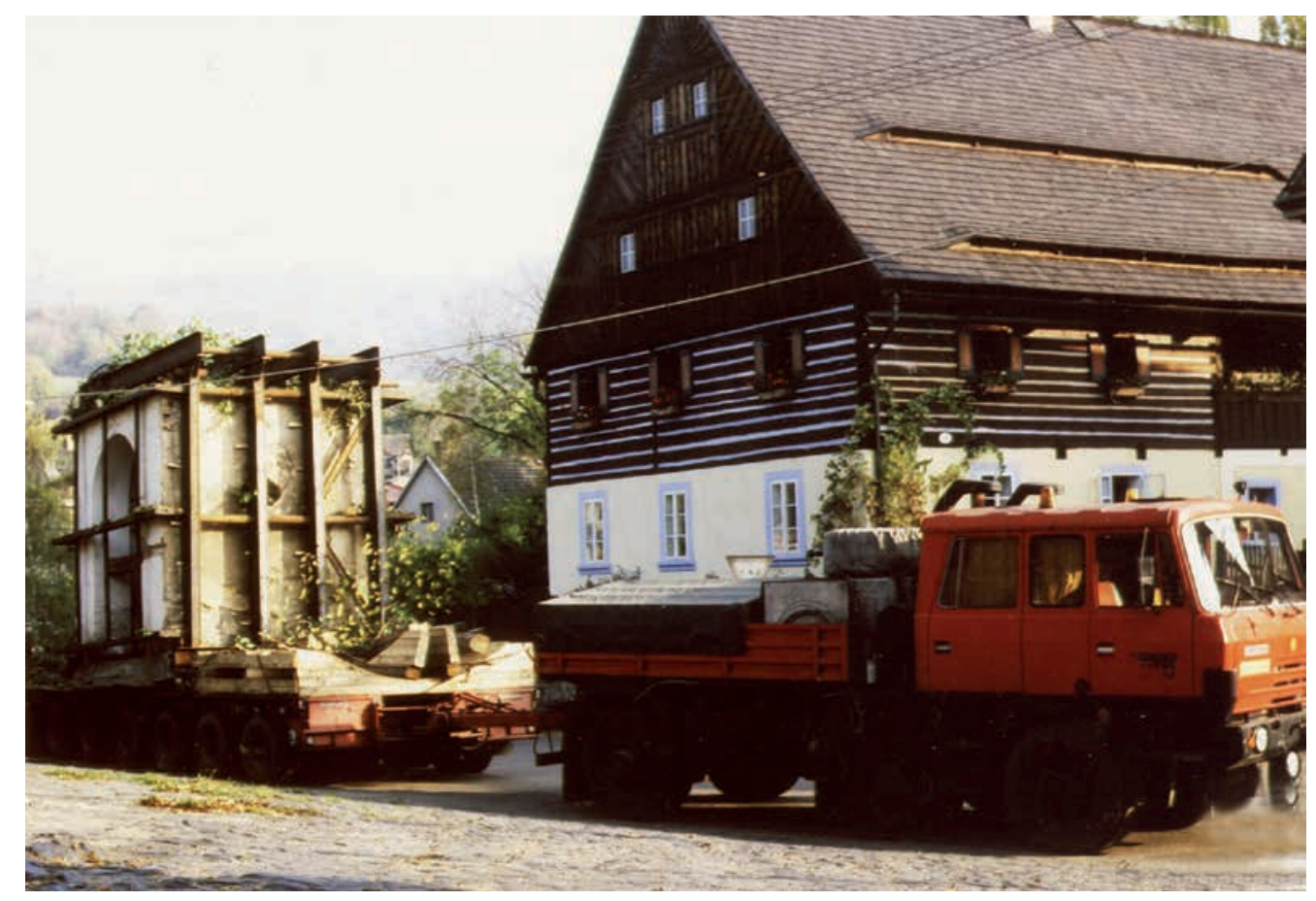

Transfer kaple ze Žichlic do Zubrnic, foto František Ledvinka, 1990 (Fotoarchiv Muzea v prírodě Zubrnice, NMvP) 
staveb středního Povltaví na Vysokém Chlumci, kde se neobvyklým způsobem podařilo skloubit záchranné, památkáŕské, ale i muzejnické a prezentační faktory ve smysluplný celek. ${ }^{55}$ Př́kladem komplexní záchrany staveb in situ se záměrem vytvoření muzea $\mathrm{v}$ prrírodě $\mathrm{z}$ onoho období je vznik souboru řemeslnických domků Betlém v Hlinsku. Uvedli jsme také některé dílč́i př́kladné aktivity dalších muzeí. Důležitým momentem v celém vývoji muzeí v př́rodě je niterná snaha o vytvoření živého muzea, které je s respektem $\mathrm{k}$ záchranné funkci staveb dodnes $\mathrm{v}$ našem prostředí obecně považováno za ideální a vzorné pojetí tohoto typu muzeí. ${ }^{56}$ Také v moderním pojetí komplexní prezentace $\mathrm{v}$ muzeích $\mathrm{v}$ prírodě je onen život pririrozeně obsažen jako jedna z neodmyslitelných složek. V př́padě nevyváženosti jednotlivých specializací se však může opomíjet př́istup ke stavebním památkám, které zde zůstávají i v rámci samotného smyslu muzeí nadále esenciálním prvkem a z pohledu pragmatického muzejnictví definovaného také legislativně prvkem zcela výsadním.

Výsledným paradoxem pak při nevyváženém př́stupu může být skutečně degradace staveb na jakési kulisy pro jakési historické divadlo, $\mathrm{v}$ lepším prrípadě pro rekonstrukci života v minulosti, kde je hodnota stavby jako muzeálie redukována na minimum. $V$ tom nejhorším př́padě se muzeum $\mathrm{v}$ prírodě může stát dokonce kulisou pro komerční aktivity, které se tak navíc ospravedlňují místem konání. Původně bohulibý směr živého muzea se tedy rozvinul natolik, že převrstvil podstatu péče o vlastní památky, které se $\mathrm{v}$ podání těchto institucí staly jen jakýmsi nástrojem pro prezentační aktivity. Takovým přístupem trpí poslední hodnoty stavebních objektů, které přežily svou komplikovanou záchranu při získání do muzea. Rekonstrukční práce jsou ovlivněny ani ne tak financemi, jako nedostatkem kvalifikovaných odborných pracovníků, ale zejména nedostatkem kvalitních řemeslníků. Málokdy si do muzea připustíme pozvat falešnou kapelu, která neumí hrát, ale $\mathrm{s}$ řemeslníky je to jiné. ${ }^{57}$
Stavební objekt muzea $\mathrm{v}$ př́rodě by měl být skutečně vnímán jako artefakt ve všech směrech. I když v současnosti primárně na konstrukční prvky a detaily muzejních objektů nestojí, na rozdíl od jiných pomíjivých kratochvílí, zástupy zájemců, uvedený stav to neomlouvá. $\mathrm{V}$ terénu i v každodenním kontaktu se setkáváme s lidmi, kteří projevují o tyto hodnoty zájem různé úrovně a následně se získanými znalostmi různě pracují. A právě na stavebních objektech je takových hodnot reprezentovaných specifickými detaily celá řada, a to jak v úrovni materiální, tak nehmotné - technologické. Samozřejmá a velmi důležitá je rovněž úloha muzeí v prrírodě jako vzoru, autority pro řadu soukromých vlastníků památek.

\section{Prameny a literatura}

BLÁHA, Jiří a kol. Operationí průzkum a dokumentace historických staveb. Praha: Národní památkový ústav, 2005.

BLÁHA， Jiří a RŮŽIČKA， Petr. Trasologický rozbor dřevěných prvků roubené polygonální stodoly usedlosti čp. 97 v Čisté. In: Průzkum a dokumentace památek lidové architektury. Rožnov pod Radhoštěm - Sebranice: Valašské muzeum v prŕrodě - Spolek archaických nadšenců, 2016, s. 174-189.

BRYOL, Radek. Devadesát let transferů do Valašského muzea $\mathrm{v}$ př́rodě v Rožnově pod Radhoštěm. In: Transfer a rekonstrukce památek lidové architektu$r y$. Rožnov pod Radhoštěm - Sebranice: Valašské muzeum $\mathrm{v}$ př́rodě - Spolek archaických nadšenců, 2016, s. 12-29.

DRÁPALA, Daniel a NOSKOVÁ, Jana. Bibliografie Národopisných aktualit 19641990. Strážnice: Národní ústav lidové kultury, 2003.

HANZLÍKOVÁ, Markéta. Transfer a následná obnova jednoho z posledních polabských domů s podsíní. In: Transfer a rekonstrukce památek lidové architektu$r y$. Rožnov pod Radhoštěm - Sebranice: Valašské muzeum $\mathrm{v}$ přírodě - Spolek archaických nadšenců, 2016, s. 84-95.

JEŘÁBEK, Richard. Výtvarný zřetel v budování národopisných muzeí
55 PROCHÁZKA, Lubomír. Muzeum vesnických staveb Středního Povltaví ve Vysokém Chlumci, pobočka Hornického muzea Príbram. Museum vivum. 2010, 6, suplementum, s. $70-75$.

56 ROMÁNKOVÁ, Eva

(ed.). Uchováno budoucím generacím. Devadesát let sbirkotvorné činnosti Valašského muzea $v$ prírodě $v$ Rožnově pod Radhoštěm. Rožnov pod Radhoštěm: Valašské muzeum v prírodě $\checkmark$ Rožnově pod Radhoštěm, 2015, s. 19; KR̆IVANOVÁ, Magda. Soubor lidových staveb Vysočina $v$ letech 1981-1997. In: Kட̆IVANOVÁ, Magda a KRAMPEROVÁ, Jana (eds.). 30 let souboru lidových staveb Vysočina: 1972-2002. Pardubice: Státní památkový ústav - Soubor lidových staveb Vysočina, 2002, s. 27. 57 Za trefný príměr děkuji kolegovi restaurátorovi Lud'ku Dvořákovi; za podnětné diskuse $k$ tématu obecně mistru tesařovi Davidu Stejskalovi. 
v př́ŕrodě, Národopisné aktuality, 1976, 13, s. 211-216.

KLOIBER, Michal a DRDÁCKÝ, Miloš. Diagnostika dřevěných konstrukcí. Praha: ČKAIT, 2015.

KŘENKOVÁ, Zuzana, KMOŠEK, Jiří a BRYOL, Radek (eds.). Transfer a rekonstrukce památek lidové architektury. Rožnov pod Radhoštěm - Sebranice: Valašské muzeum v prrírodě - Spolek archaických nadšenců, 2016.

Ǩ̌IVANOVÁ, Magda. Soubor lidových staveb Vysočina $\mathrm{V}$ letech 1981-1997. In: KŘIVANOVÁ, Magda a KRAMPEROVÁ, Jana (eds.). 30 let souboru lidových staveb Vysočina: 1972-2002. Pardubice: Státní památkový ústav - Soubor lidových staveb Vysočina, 2002, s. 27-29.

LANGER, Jiří. Evropská muzea v př́rodě. Praha: Baset, 2005.

LANGER, Jiří. Generační aspekt prezentace lidové výroby v muzeích v prrírodě. In: Lidová výroba. Její dokumentace a prezentace. Vsetín: Okresní vlastivědné muzeum, 1995, s. 4-13.

LANGER, Jiří. Lidové stavby v České republice. Praha: Národní památkový ústav, 2019.

LANGER, Jiří. Luděk Štěpán odešel. Museum vivum, 2017, 12, s. 140-141.

LANGER, Jiří. Úspěchy a prohry Valašského muzea $\mathrm{v}$ prrírodě. Museum vioum, 2014/2015, 10, s. 74-84.

LANGER, Jiří a SOUČEK, Jan. Problémy rozvoje muzeí $\mathrm{v}$ přírodě v Československu. Národopisné aktuality, 1980, 17, č. 1, s. 1-10.

LANGER, Jiří a ŠTIKA, Jaroslav. Československá muzea v př́rodě. Martin: Osveta, 1989.

LEDVINKA, František. Práce s hlínou v zubrnickém skanzenu. In: VÁLKA, Miroslav a MALACH, Roman. Vesnická stavební kultura. Stavební materiál - domová dispozice - slohové ohlasy - dřevěné sakrální stavby. Brno: Masarykova univerzita, 2014, s. 87-96.

MICHALIČKA, Václav. Některé aspekty revitalizace tradičních technologií lidového stavitelství. Národopisná revue, 2010, 20, s. 79-83.
NOVOTNÝ, Martin. Hliněné stavitelství na Moravě a evropské souvislosti. Kritický katalog k výstavě. Strážnice: Národní ústav lidové kultury, 2014.

PELUNĚK, Lukáš F. Neuskutečněné plány založení Bartošova národopisného musea $\mathrm{v}$ přírodě. $\mathrm{K}$ životnímu odkazu Ladislava Rutteho (1893-1967). In: WOITSCH, Jiří a JŮNOVÁ MACKOVÁ, Adéla (eds.). Etnologie v zúženém prostoru. Praha: Etnologický ústav AV ČR, 2016, s. 364-372.

PROCHÁZKA, Lubomír. Muzeum vesnických staveb Středního Povltaví ve Vysokém Chlumci, pobočka Hornického muzea Př́ibram. Museum vivum, 2010, 6, suplementum, s. 70-75.

PROCHÁZKA, Lubomír. Transfer klenby černé kuchyně obytného stavení Obděnice čp. 4 (okr. Příbram) do Muzea vesnických staveb středního Povltaví ve Vysokém Chlumci. Středočeský vlastivědný sborník, 2001, sv. 19, s. 123-125. PODROUŽEK, Kamil a kol. Metodika dokumentace lidové architektury. Ústí nad Labem: Národní památkový ústav Filozofická fakulta univerzity J. E. Purkyně, 2015.

RIŠLINK, Vladimír a P̌̌ENOSILOVÁ, Dana. Kouřimský skanzen od založení k dnešku. Museum vivum, 2010, 6, suplementum, s. 83-93.

ROMÁNKOVÁ, Eva (ed.). Uchováno budoucím generacím. Devadesát let sbírkotvorné činnosti Valašského muzea v př́rodě $v$ Rožnově pod Radhoštěm. Rožnov pod Radhoštěm: Valašské muzeum v přírodě v Rožnově pod Radhoštěm, 2015.

SMOLÍK, Luboš. Aktivity klatovského muzea v letech 1990-2005 - expozice lidové architektury v Chanovicích. Museum vivum, 2006, 2, s. 59-62.

SMRČKA, Vít. Dějiny psané národopisem. Praha: Česká národopisná společnost, 2011.

SOUČEK, Jan. Stavební památky v komplexu muzejní činnosti Ústavu lidového umění ve Strážnici. Národopisné aktuality, 1976, 13, č. 3, s. 191-200.

SOUČEK, Jan a MÁČEL, Otakar. Od myšlenky $\mathrm{k}$ realizaci expozice lidových zemědělských staveb ve Strážnici. 
Národopisné aktuality, 1974, 11, č. 1, s. 33-56.

ŠTĚPÁN, Luděk. Metodická pomoc Valašského muzea $\mathrm{v}$ př́ŕrodě $\mathrm{v}$ začátcích Souboru lidových staveb Vysočina. Museum vivum, 2013, 9, s. 33-34.

ŠTĚPÁN, Luděk. Soubor lidových staveb Vysočina - Dvacet let od zpřístupnění prvního objektu. Zprávy památkové péče, 1992, 52, č. 8, s. 19-22.

ŠTĚPÁN, Luděk. Začátky souboru lidových staveb Vysočina (do roku 1981). In: Ǩ̌IVANOVÁ, Magda a KRAMPEROVÁ, Jana (eds.). 30 let souboru lidových staveb Vysočina: 1972-2002. Pardubice: Státní památkový ústav Soubor lidových staveb Vysočina, 2002, s. 21-25.

ŠTĚPÁN, Luděk. 15 let Souboru lidových staveb a řemesel Vysočina. Památky a príroda, 1987, 47, s. 217-220.

ŠTĚPÁNEK, Ladislav. K problematice a formám národopisných muzeí v přírodě Středočeského kraje. Národopisné aktuality, 1971, 8, č. 1, s. 74-75.

ŠTĚPÁNEK, Ladislav. K ochraně lidových staveb v muzeích v přírodě. Národopisné aktuality, 1968, 5, č. 3-4, s. 277-279.

ŠTĚPÁNEK, Ladislav. Třebíz - muzeum sociálního rozvrstvení vesnice. Národopisné aktuality, 1975, 12, č. 1, s. 79-80.

ŠTIKA, Jaroslav. Idea Valašského muzea v př́rodě, její vývoj a proměny. In: Almanach k 75. výročí založení Valašského muzea v př́rodě v Rožnově pod Radhoštěm. Rožnov pod Radhoštěm: Valašské muzeum v př́rodě, 2000, s. 9-21.

ŠULĚ̌r, Petr. Autenticita - identita, aneb o potřebě užitečného napětí. Národopisné aktuality, 1980, 17, č. 1. s. 73-75.

SVOBODOVÁ, Jana. Muzeum lidových staveb v Kouřimi. Museum vivum, 2010, 6, suplementum, s. 94-100.

TICHÁ Jana. Roubený seník s kamenným sklepem z Nového Hrozenkova -
Břežitá. Rekonstrukce historické podoby původního objektu pro realizaci ve Valašském muzeu $\mathrm{v}$ přírodě. Museum vioum, 2009, 5, s. 113-117.

TICHÁ, Jana. Řezbář a mistr tesař lidových staveb Michal Žitník. Museum vivum, 2014/2015, 10, s. 185-187.

TYKAL, Roman. Český mlýn na Národopisné výstavě českoslovanské. Prameny a studie, 2015, 56, s. 191-195.

VA ̌̌EKA, Josef a FROLEC, Václav. Lidová architektura. Encyklopedie. Praha: Grada, 2007.

VÁLKA, Miroslav. Lidový dům a jeho role při formování národní identity. Prameny a studie, 2015, 56, s. 147-158.

VÁLKA, Miroslav. Soubor lidových staveb východní Hané v Rymicích u Holešova a jeho záchrana. Národopisné aktuality, 1979, 16, s. 325-326.

VÁLKA, Miroslav. Větrný mlýn ve Velkých Těšanech obnoven. Národopisné aktuality, 1980, 17, č. 1, s. 75.

VRLOVÁ, Vanda. Miloňov v rožnovském muzeu už 55 let. Valašsko, vlastivědná revue, 2018, 41, č. 2, s. 30-31.

ZÍBRT, Čeněk. Valašské museum v přírodě. Český lid, 1928, 28, s. 154-159.

Národní muzeum v přírodě - Valašské muzeum $\mathrm{v}$ přírodě $\mathrm{v}$ Rožnově pod Radhoštěm, Oddělení dokumentace, S III 01, Spolková činnost, Musejní spolek v Rožnově, inv. č. A 20082. 1929.

Kauza PhDr. Jiří Langer, CSc. vs. Valašské muzeum $\mathrm{v}$ přírodě $\mathrm{v}$ Rožnově pod Radhoštěm. Dostupné z: http://www. narodopisnaspolecnost.cz/old/kauza. php, cit. 20. 5. 2020.

Dostavba skanzenu v Přerově na Labem. Dostupné z: http://www.roman-abusinov.cz/, cit. 28. 8. 2020. 